\title{
Effects of Clear Kefir on Biomolecular Aspects of Glycemic Status of Type 2 Diabetes Mellitus (T2DM) Patients in Bandung, West Java [Study on Human Blood Glucose, c Peptide and Insulin]
}

\author{
Judiono $\mathrm{J}^{1^{*}}$, Suharyo Hadisaputro ${ }^{2}$, Indranila $\mathrm{KS}^{3}$, Bambang Cahyono ${ }^{4}$, Meiny Suzery, ${ }^{4}$ \\ Yuliati Widiastuti ${ }^{5}$, Asep Iwan Purnawan ${ }^{6}$
}

${ }^{1}$ Head of Nutrition Department, The Bandung Health Polytechnic, MOH R.I, Indonesia; ${ }^{2}$ Graduate School of Diponegoro University Semarang, Indonesia; ${ }^{3}$ The Clinical Pathology Specialist Division at Medicine Faculty of University Semarang, Indonesia; ${ }^{4}$ Science and Math Faculty University Semarang, Indonesia; ${ }^{5}$ Chief of Clinical Dietitian The Bandung Saint Borromeus Hospital, Indonesia; ${ }^{6}$ Nutrition Biomolecular Division, The Bandung Health Polytechnic, MOH R.I, Indonesia

*Corresponding author: Judiono J., PhD, The Bandung Health Polytechnic, MOH R.I, Indonesia, Jl. Padjajaran No. 56 Bandung, West Java, 40173, Indonesia

Submission date: January 10, 2014; Acceptance date: July 29, 2014; Publication date: August 5, 2014

\begin{abstract}
Background: Diabetes Mellitus (DM) triggers an excessive reaction of free-radicals. It increases reactive oxygen species and reduces antioxidants status as well as the $\beta$ cell damage. Clear kefir was used for DM therapies, however it limited biomolecular exploration of its bioactive roles. Research aimed to investigate the effects of clear kefir on the biomolecular nature of the glycemic status of T2DM in Bandung.
\end{abstract}

Methods: The randomized pretest-posttest control group was conducted by 106 T2DM patients. Research was done in several hospitals in Bandung and Cimahi, West Java from 2012-2013. Samples were divided randomly into three groups: (1) T2DM with $\mathrm{HbA}_{1 \mathrm{c}}<7$ was fed a standard diet, supplemented with $200 \mathrm{ml} /$ day of clear kefir, (2) T2DM with $\mathrm{HbA}_{1 \mathrm{c}}>7$ fed standard diet and supplemented $200 \mathrm{ml} /$ day by clear kefir, (3) T2DM with $\mathrm{HbA}_{1 \mathrm{c}}$ was fed a standard diet as a control group. Dose response was obtained from a preeliminary vivo study, and then converted to human dosage by year 2011. Intervention was effectively done for 30 days. $\mathrm{HbA}_{1 \mathrm{c}}$ was measured by HPLC. Fasting blood glucose (FBG) and Postprandial blood glucose levels (PBG) were measured by enzymes levels. $\mathrm{C}$ Peptide and insulin were measured by Elisa. Data was analyzed by a statictics programme by significance $\mathrm{p}<0,05$. Study was approved by ethic committee. 
Results : $\mathrm{HbA}_{1 \mathrm{c}}$ was significantly reduced in delta level $(\mathrm{p}<0.01)$ and FBG $(\mathrm{p}<0.015)$ among kefir groups. PBG was not significantly reduced among groups. C-Peptide was significantly increased in delta level, except in control group $(\mathrm{p}<0.014)$. Insulin was reduced significantly, except in control group ( $\mathrm{p}<0.003)$.

Conclusions : Supplementation of clear kefir reduced blood glucose levels ( $\mathrm{HbA}_{1 \mathrm{c}}$, FBG, $\left.\mathrm{PBG}\right)$ and increased c-peptide. Clear kefir's biomolecular mechanisms and chemistry characterization is a challenge for future studies.

Keywords : Diabetes melitus, hyperglicemia, clear kefir, insulin, c peptide

\section{BACKGROUND:}

Diabetes mellitus is a metabolic disorder which is characterized by hyperglycemic syndrome. The prevalence of type 2 diabetes increased yearly in Indonesia.The number of patients was predicted to increase from 8.4 million in year 2000 to 21.3 million in year 2030 in this country [1]. Untreated, this disease will cause severe complications, such as: nephropathy, neurophaty and retinopaty. Consequently, it will decrease the quality of long term human resources [2]

Hyperglycemia caused the pancreatic $\beta$ cells to dysfunction [3]. Hyperglicemia enhanced the formation of free radicals and caused oxidative stress. Free-radicals increased through various channels, such as: (1) non-enzymatic glycation (AGEs), (2) glucose auto-oxidation, (3) polyol pathway and protein kinase (PKC) $[4,5,6,7,8]$. As a result, it triggered an increase in free fatty acids, lipid peroxidation and proinflammatory cytokine production. It diminished the Langerhans organs, granule secretion of insulin, decreased the $\beta$ cells volume by $60 \%$ [9], and immune response. Oxidative stress reduced antioxidants capacity and lead to defective insulin secretion and gene expression. Furthermore, proinflammatory cytokines triggered and activated the receptor of kinase inhibitor factors, NFkB and stimulated pancreatic $\beta$ cell damageto pancreatic $\beta$ cell apoptosis by inhibiting the insulin signal $[10,11,12,13]$.

The $\beta$ cells regeneration so far, is the newest insight in diabetic therapy. It can be applied through several approaches. The first is reduction of lipid peroxidation, and blood glucose. It will respectively inhibit proinfamatory cytokines production. Increased number in an endogenous antioxidant enzyme in the body, may decrease oxidative stress. In addition, the best $\beta$ cell regeneration can be a systematic effort from inside his own body by provision of the quality of nutrition intake such as protein. Protein can be enhanced to maintain and regenerate body cells.

The available diabetes therapy has been unsuccessful in optimally controlling blood glucose levels [14]. The use of insulin and medication are the most effective options, but it is difficult to be implemented on an ongoing basis with respect to several reasons, such as: socioeconomic, residual and knwoledge barriers. Attempts on the induction of pancreatic $\beta$ cell regeneration by using immunotherapy probiotics [15] are never reported elsewhere, but the results have been conflicting in relation to the application of therapy. Further studies are therefore important to ensure consistency in results. 
Clear kefir supplementation offers several bioactive compounds, such as exopolyssacharide, peptide, antioxidant and immunomodulatory properties [16, 17, 18, 19]. Kefir's peptide enhanced the biological values and the digestibility of protein. It was also supported by Meier and Almatsier, that the best efforts for $\beta$ cell regeneration is through a systematic effort from inside his own body.High quality nutrition intake, especially a high biological value of protein is very important, because protein will maintain and regenerate the body's cells [20, 21]. Kefir is also able to activate the regulatory $T$ (Treg) role which functions to maintain homeostasis in $\mathrm{Th}_{1}-\mathrm{Th}_{2}$ responses. The mechanism underlying is strengthened by the immune system via normalized pro-inflammation cytokine production. Through their cytokine products, these cells enable suppression ofinflammatory reactions, and increased production of interleukin $10\left(\mathrm{IL}_{10}\right)$ in pancreatic $\beta$ cells. $\mathrm{IL}_{10}$ suppressed proinflammatory response and apoptosis [22].

Kefir bening is a low-fat milk fermented by kefir grains. Kefir grains are symbiotic bacterias and yeast colonies. This fermentor containsmore than 35 beneficial healthy probiotic bacterias. It is also simple to produce and easy to be implemented in the household on an industrial scale.

The research aimed to investigate clear kefir effects on the biomolecular aspects of the glycemic status of T2DM in Bandung. It was measured by parameters like $\mathrm{HBA}_{1 \mathrm{c}}$, Blood Glucose, Insulin and c-peptides among diabetes outpatients in several hospitals in Bandung and Cimahi.

\section{METHOD AND MATERIALS:}

This research was randomized; control group pretest-posttest design [23] was conducted on 108 diabetes mellitus out patients in several Hospitals in Bandung and Cimahi from 2012-2013. Samples were strictly selected by inclusion such as: T2DM patients based on the doctor's diagnosis, and treated them with the last blood glucose level at about $<200 \mathrm{mg} / \mathrm{dL}, \mathrm{HbA}_{1 \mathrm{c}}$ equivalent 6-8; no complications, illness, amples inclusion, or using same DM medication, were in the informed consent. Samples were divided randomly into three groups: (1) T2DM with $\mathrm{HbA}_{1 \mathrm{c}}<7$ fed a standard diet and supplemented $200 \mathrm{ml} /$ day by clear kefir, (2) T2DM with $\mathrm{HbA}_{1 \mathrm{c}}>7$ fed a standard diet and supplemented $200 \mathrm{ml} /$ day by clear kefir, (3) T2DM with $\mathrm{HbA}_{1 \mathrm{c}}$ fed a standard diet as control group. Kefir's dose response was obtained and adapted from the research result of a preelimary in vivo study in 2011. Intervention was accomplished effectively during 30 days.

Preparation of Mother Kefir. Standardize the milk for preparation of mother kefir. Pasteurize skim milk at $90-95^{\circ} \mathrm{C}$ for $15 \mathrm{~min}$ and cool to $18-22^{\circ} \mathrm{C}$. Spread kefir grains at the bottom of a container (5-10 cm thick) and add pasteurized milk (20-30 times the volume of kefir grains). Ferment for 18-24 h, mixing 2-3 times. Kefir grains float to the surface. Filter out the kefir grains with a fine sieve; wash the grains with water and save for the next fermentation. Save the fermented milk for the next-step, which is inoculation.

Preparation of Drinkable Clear Kefir. Blend fermented skim milk from above with 8-10 times the volume of fresh, pasteurized, and untreated milk. Filter into bottles, close and fement for 1-3 days at $18-22{ }^{\circ} \mathrm{C}$ (room temperature) until the minimum standards for lactic acid bacterias (LAB) are achieved at $10^{7} \mathrm{cfu} / \mathrm{g}$. Another option is to mix the fermented milk with fresh milk at $1-5 \%$; fermented at $18-25^{\circ} \mathrm{C}$ for $12-15 \mathrm{~h}$ until reaching $\mathrm{pH} 4.4-4.5$, followed by 
ripening in refrigerated storage tanks for $1-3{ }^{\circ} \mathrm{C}$ Kefir grains are commercial inoculum that are acquired from the House of Kefir Bening Semarang.

Blood glucose consisted of fasting blood glucose (FBG), postprandial blood glucose (PBG) were measured by enzymatic methods. $\mathrm{HbA}_{1 \mathrm{c}}$ was measured by HPLC. C-peptide and insulin were measured by Elisa. Statistical analysis presented of univariate data (mean, SD), bivariate (Kruskal Wallis, Mann Whitney with a significance level 0.05.)

This research was approved by the Research Ethics Committee for Health Research, Medicine Faculty, Diponegoro University, Semarang and Dr. Kariadi General Hospital, Semarang.

\section{RESULTS:}

Research showed that fasting blood glucose (FBG) levels were decreased during study in both samples and the control groups. The best achievement reduction in fasting blood glucose levels were highest in group 2. It revealed that the average reduction is equal to $-34.06 \mathrm{mg} / \mathrm{dL}$ and with a standard deviation about $55.12 \mathrm{mg} / \mathrm{dL}$ by group 2 , and group 1 reduced about $-19.4286 \pm$ $18.64 \mathrm{mg} / \mathrm{dL}$. The statistical analysis indicated that there was a significant reduction in FBG levels in all three study groups $(\mathrm{p}=0.015)$. The table 1 presented research result Biomolecular Aspects of Glycemic Satatus of Type 2 Diabetes Mellitus (T2DM) Patients in Bandung, West Java

Table 1. Biomolecular Aspects of Glycemic Satatus of Type 2 Diabetes Mellitus (T2DM) Patients in Bandung, West Java

\begin{tabular}{|c|c|c|c|c|c|c|c|c|c|c|c|}
\hline \multirow{4}{*}{ No } & \multirow{4}{*}{ Variables } & \multicolumn{9}{|c|}{ Research groups } & \multirow{4}{*}{$\begin{array}{c}\text { Change } \\
\text { of delta } \\
(\Delta) \\
\mathrm{p}\end{array}$} \\
\hline & & \multicolumn{3}{|c|}{ Group 1} & \multicolumn{3}{|c|}{ Group 2} & \multicolumn{3}{|c|}{ Group 3 (control) } & \\
\hline & & Pre-test & $\begin{array}{l}\text { Post- } \\
\text { test }\end{array}$ & $\begin{array}{l}\text { Change } \\
\text { of delta } \\
(\Delta)\end{array}$ & Pre-test & $\begin{array}{l}\text { Post- } \\
\text { test } \\
-\end{array}$ & $\begin{array}{c}\text { Change } \\
\text { of delta } \\
(\Delta)\end{array}$ & Pre-test & $\begin{array}{l}\text { Post- } \\
\text { test } \\
-\end{array}$ & $\begin{array}{c}\text { Change } \\
\text { of delta } \\
(\Delta)\end{array}$ & \\
\hline & & $\bar{\chi} \pm \mathrm{SD}$ & $\bar{\chi} \pm \mathrm{SD}$ & $\bar{\chi} \pm \mathrm{SD}$ & $\bar{\chi} \pm \mathrm{SD}$ & $\bar{\chi} \pm \mathrm{SD}$ & $\bar{\chi} \pm \mathrm{SD}$ & $\bar{\chi} \pm \mathrm{SD}$ & $\bar{\chi} \pm \mathrm{SD}$ & $\bar{\chi} \pm \mathrm{SD}$ & \\
\hline 1 & $\begin{array}{l}\text { FBG } \\
(\mathrm{mg} / \mathrm{dL})\end{array}$ & $\begin{array}{c}144.74 \\
\pm 28.74\end{array}$ & $\begin{array}{c}125.31 \\
\pm 27.43\end{array}$ & $\begin{array}{r}(-19.43 \\
\pm 18.64)\end{array}$ & $\begin{array}{r}188.94 \\
\pm 71.40\end{array}$ & $\begin{array}{r}154.89 \\
\pm 39.53\end{array}$ & $\begin{array}{c}(-34.06 \\
\pm \\
55.12)\end{array}$ & $\begin{array}{r}178.72 \\
\pm 74.28\end{array}$ & $\begin{array}{r}175.81 \\
\pm 70.79\end{array}$ & $\begin{array}{c}(-2.92 \pm \\
66.59)\end{array}$ & $0.015^{*}$ \\
\hline 2 & $\begin{array}{l}\text { PBG } \\
(\mathrm{mg} / \mathrm{dL})\end{array}$ & $\begin{array}{r}213.60 \\
\pm 45.43\end{array}$ & $\begin{array}{c}156.97 \pm \\
41.90\end{array}$ & $\begin{array}{c}(-56.63 \\
\pm \\
42.1070)\end{array}$ & $\begin{array}{r}258.66 \\
\pm 62.97 \\
\end{array}$ & $\begin{array}{r}195.80 \\
\pm 73.87 \\
\end{array}$ & $\begin{array}{c}(-62.86 \\
\pm \\
57.44)\end{array}$ & $\begin{array}{r}262.25 \\
\pm 61.35\end{array}$ & $\begin{array}{r}234.78 \\
\pm 81.34\end{array}$ & $\begin{array}{c}(-28.47 \\
\pm \\
69.35)\end{array}$ & 0.097 \\
\hline 3 & $\begin{array}{l}\text { Insulin } \\
(\mathrm{pg} / \mathrm{mL})\end{array}$ & $\begin{array}{c}3.76 \pm \\
6.0 \\
\end{array}$ & $\begin{array}{c}3.08 \pm \\
3.94\end{array}$ & $\begin{array}{c}(-1.68 \pm \\
4.93)\end{array}$ & $\begin{array}{c}18.67 \pm \\
8.24\end{array}$ & $\begin{array}{c}17.67 \pm \\
8.08\end{array}$ & $\begin{array}{c}(-1.21 \\
\pm 2.93) \\
\end{array}$ & $\begin{array}{c}15.21 \pm \\
9.65\end{array}$ & $\begin{array}{c}13.43 \pm \\
9.83 \\
\end{array}$ & $\begin{array}{c}(-1.79 \pm \\
2.58)\end{array}$ & $0.003^{*}$ \\
\hline 4 & $\begin{array}{l}\text { c-peptide } \\
(\mathrm{pg} / \mathrm{mL})\end{array}$ & $\begin{array}{c}0.86 \pm \\
0.80\end{array}$ & $\begin{array}{c}0.94 \pm \\
0.76\end{array}$ & $\begin{array}{c}0.68 \pm \\
0.18\end{array}$ & $\begin{array}{c}0.68 \pm \\
0.44\end{array}$ & $\begin{array}{c}0.75 \pm \\
0.48\end{array}$ & $\begin{array}{c}0.07 \pm \\
0.12\end{array}$ & $\begin{array}{c}0.12 \pm \\
0.68\end{array}$ & $\begin{array}{c}0.11 \pm \\
0.68\end{array}$ & $\begin{array}{l}(-0.016 \\
\pm 0.06)\end{array}$ & $0.014^{*}$ \\
\hline 5 & $\begin{array}{l}\text { HbA1c } \\
(\mathrm{pg} / \mathrm{mL})\end{array}$ & $\begin{array}{c}6.56 \pm \\
0.32\end{array}$ & $\begin{array}{c}6.43 \pm \\
0.33\end{array}$ & $\begin{array}{c}(-0.13 \pm \\
0.15)\end{array}$ & $\begin{array}{c}8.04 \pm \\
0.92\end{array}$ & $\begin{array}{c}7.95 \pm \\
0.79\end{array}$ & $\begin{array}{c}(-0.09 \pm \\
0.24)\end{array}$ & $\begin{array}{c}8.20 \pm \\
1.71\end{array}$ & $\begin{array}{c}8.20 \pm \\
1.71\end{array}$ & $\begin{array}{c}0.001 \pm \\
0.01\end{array}$ & $0.001^{*}$ \\
\hline
\end{tabular}

*Kruskal Wallis significancy by $\mathrm{p}<0.05$

All groups revealed reduced post prandial blood glucose (PBG), however the higgest reduction was established in about $-62.86 \pm 57.44 \mathrm{mg} / \mathrm{dL}$ by group 1 . In addition, Group 2 
showed a reduction of about $-56.6286 \pm 42.1070 \mathrm{mg} / \mathrm{dL}$. Statistical analysis showed that there was no significant increase among samples (intervention groups and control).

Moreover, insulin levels decreased during study in both the samples and control groups. The best achievement insulin levels were slowest by group 2 . It revealed an average reduction equal to $-1,68 \pm 4.93 \mathrm{pg} / \mathrm{mL}$, then it followed the reduction in average of about $-1.21 \pm 2.93 \mathrm{pg} / \mathrm{mL}$ in group 2. The statistical analysis indicated that there was a significant reduction in FBG levels in all three study groups $(\mathrm{p}=0.003)$.

The best achievement in c-peptide levels were the increase by group 1. Group 1had an average c-peptide level increase of about $0.68 \pm 0.18 \mathrm{pg} / \mathrm{mL}$. It was followed by group 2 by about $0.07 \pm 0.12 \mathrm{pg} / \mathrm{mL}$. In contrast, the control group (group 3) tended to reduce by $-0.02 \pm 0.06$ $\mathrm{pg} / \mathrm{mL}$. Kefir has the potential to increase c-peptide levels because statistical analysis showed a significant difference of increase among groups.

$\mathrm{HBA}_{1 \mathrm{c}}$ of research samples varied among the groups, except of the control group. The control was gained with very small achievement in average about $0,001 \pm 0,001$. Other groups were proven to reduce with achievement in group 1 of about $-0.13 \pm 0.15$, and Group was also reduced by about $-0.09 \pm 0.24$. Statistical analysis respectively found significant difference among groups of samples ( $\mathrm{p}>0.05)$.

Kefir is a healthy drink and hipocaloric. The results of the proximate analysis showed clear kefir levels of nutrients, such as: Energy obtained ranged $70.48 \mathrm{Kcal}$, fat content about $1.32 \mathrm{~g}$. Trace elements improved at the $132 \mathrm{~g}$ calcium. Micronutrients were found, such as vitamin A, at about 220 IU. Table 2, shows a table of nutritional contents in kefir.

Table 2. Nutrition contents of clear kefir serving in $100 \mathrm{ml}$

\begin{tabular}{llr}
\hline No. & Nutrients & $\begin{array}{c}\text { Content } \\
\text { per } 100 \mathrm{ml}\end{array}$ \\
\hline 1 & Energy (Kcal) & 70.48 \\
2 & Protein (g) & 6.16 \\
3 & Carbohydrate (g) & 3.52 \\
4 & Fat (g) & 1.32 \\
5 & Natrium (mg) & 90.00 \\
6 & Calcium (mg) & 132.00 \\
7 & Vitamin A (IU) & 220.00 \\
8 & Vitamin B (IU) & 44.00 \\
\hline
\end{tabular}

\section{DISCUSSION:}

This study has been demonstrateing that the supplementation of clear kefir $200 \mathrm{ml} / \mathrm{day}$, for 30 days, significantly affects blood glucose and c-petide levels. Clear kefir reduced hyperglycemia and oxidative stress conditions. The mechanism underlying is probably caused by the reduction of oxidative stress. It played a critical role in decreasing the blood lipid peroxidation levels that are measured by malondealdehyde (MDA). Peroxide molecules may positively effect 
proinflammatory cytokine $\left(\mathrm{IL}_{1}, \mathrm{IL}_{6}, \mathrm{TNF} \alpha\right.$ ) production. Those cytokines inhibit insulin signals by activating the factor receptor kinase inhibitor, stimulating NFkB to pancreatic $\beta$ cell damage and apoptosis [24]. Moreover, insulin also increased the synthesis of protein used for the formation of new cells, including pancreatic $\beta$ cells. Insulin has structurally and functionally similar molecules, including insulin-like growth factors, where its tertiary structure has a growth stimulant that forces the pancreatic $\beta$ cells into regeneration.

In addition, clear kefir also proved to effect pancreatic $\beta$ cell regeneration. This mechanism underlying caused byits bioactive components, such as peptides and amino acids (AA). This peptide induced a highly biological protein and digestibility values, and as result, it continued to maintain and regenerate cells. Kefir enhances the usability of biological proteins and fats as well as the production of amino acids such as glutamine, arginine and nucleotides by the hydrolysis of enzymes and bacteria hydrolysis. The nucleotide is basically needed for establishing and working arrangements of proteins in the small intestine, liver and lymph nodes, as well as for genetic mechanisms. This result correlated with a former finding in the vivo study where the result showed clear kefir supplementation. It was systemically repairing and regenerating cells in the number of normal pancreatic $\beta$ cells of Langerhans island during the intrevention process [24].

Pancreatic $\beta$ cell regeneration will lead to the restoration of pancreatic $\beta$ cell mass, as a result of the restoration of physiology and insulin secretion. Other mechanisms can be done through preventative techniques against glucotoxicity and lipotoxicity, which empties into the occurrence of hyperglycemia, and gives substances act to reduce the occurrence of hyperglycemia.

Clear kefir prevented glucotoxiticity and lipotoxiticity, and reduced the occurrence of hyperglycaemia. The mechanism underlying is accomplished via exopolissacharides. Bioactive exsopolyssacharides (EPS) have been activating the hormone glucagon, which is similar to peptide 1 (GLP 1), gastric inhibitory peptide (GIP) and the enzyme adenylate cyclase through the cyclic adenosine monoposfat (cAMP), sensitization of $\mathrm{Ca}^{2}$ ions and activation of protein kinase A, thus increasing insulin release from the pancreatic $\beta$ cells. Then, the glucose can be utilized by the body tissues and cells. Another mechanism underlying was probably EPS modulated of insulin signaling via c-AMP [25] [26]. Increased c-AMP in pancreatic cells revealed and contributed to better insulin secretion from pancreatic $\beta$ cells.

Conclusions and Recommendations: Supplementation of clear kefir proved to reduce blood glucose $\left(\mathrm{HbA}_{1 \mathrm{c}}\right.$, FBG, $\left.\mathrm{PBG}\right)$ and increase c-peptide by $200 \mathrm{ml}$ a day for 30 days.

Competing interests: The authors declare that they have no competing interests with anyone or with any organizations.

\section{Abbreviations:}

DM, diabetes mellitus; T2DM, type 2 diabetes mellitus; $\mathrm{HbA}_{1 c}$, glycated haemoglobin; FBG, Fasting Blood Glucose; PBG, Postprandial Blood Glucose; AGEs, non-enzymatic glycated haemoglobin glycation; PKC, protein kinase; oxidative stress; NFKB, necrosis factor 
kappa beta; ROS, reactive oxigen species; Treg, T regulator, IL10, Interleukin 10; Th1 Th2, T helper 1 and 2.

Authors' Contributions: All authors contributed to this study. Judiono designed and conducted the study, performed the data analysis (including the statistical analysis) and drafted the manuscript. Suharyo Hadisaputro initiated the study, supervised and co-designed the entire study, and also co-revised and edited the manuscript in its entirety. Indranila KS performed and supervised blood specimen Elisa analysis. Bambang Cahyono and Meiny Suzery provided data antioxidants analysis. Asep Iwan Purnawan performed and helped to enter data for running statistical analysis. Yuliati Widiastuti performed assesing nutritional status, and clear kefir and dietetic intervention.

Anknowledgement: This study was financially supported by Indonesian Danone Institute Foundation. The views expressed herein are those of the individual authors, and do not necessarily reflect those of Indonesian Danone Institute Foundation. We express our gratitude to honourable Professor Dr. Sukirman, MPS ID, Professsor RRJ. Djokomoeljanto ${ }^{(\dagger)}$, Professor Endang Purwaningsih ${ }^{(\dagger)}$, Dr. Yusron, SpPD, (an Internist of Military Army Hospital Cimahi) Dr. V. Dhian Rusnasari, SpPD (an Internist of The Bandung Saint Yosep Hospital), who has given her support and ideas on the implementation of this study. Cebior Cq. GAKY Biomolecular Laboratory University of Diponegoro Semarang, Integrated Biomolecular Laboratory The Bandung Health Polytechnic, MOH R.I.

\section{REFERENCES:}

1. WHO. Prevalence of diabetes worldwide. 2008. http: //www.who.int/ diabetes/facts /world_figures/en/

2. Hadisaputro, S., Setyawan, H. 2007. Faktor-Faktor yang berpengaruh terhadap kejadian Diabetes mellitus tipe 2, Naskah Lengkap Diabetes Melitus Ditinjau dari Berbagai Aspek Penyakit Dalam. Semarang: Badan Penerbit Universitas Diponegoro. 2007: p. 133-154

3. Brownlee, Michael. 2004. Banting Lecture 2004. The Pathobiology of Diabetic Complications. A Unifying Mechanism. Diabetes, Vol. 54, June 2005. Page 1615- 1624

4. Betteridge, D.J. 2000. What is oxidative stress? Metabolism Clinical and Experimental, (49), 2, Supplemen 1, 2000: p. 3-6

5. Ceriello, A. 2000. Oxidative Stress and Glycemic Regulation. Metabolism (49),2 Supplement 2000: p. 27-29

6. Pfaffy, 2001. Diabetic Complications, Hyperglicemia \& Free Radicals. Biosciences Departement The University of Iowa. Iowa City, 2001. 52242

7. Djokomoeljanto. RRJ. 2007. Neuropati Diabetik dalam Naskah Lengkap Diabetes Melitus ditinjau dari berbagai Aspek penyakit dalam editor Darmono, dkk. Badan Penerbit Universitas Diponegoro, 2007. Hal. 1-14

8. Soeyono, Slamet. 2005. Resistensi insulin, Disfungsi sel $\beta$ dan Peran antioksidan dalam terapi diabetes melitus. Prosiding Pekan Ilmiah Nasional Assosiasi Dietisien Indonesia, 2005 
9. American Diabetes Association (ADA). 2008. Diagnosis dan Clasification of Diabetes Melitus. Jurnal Diabetes Care, 2008. (31), 1, January 2008

10. Maritim, A.C., R.A. Sanders., J.B. Watkins III. 2003 Diabetes, Oxidative Stress, and Antioxidants : A Review. J. Biochem Molecular Toxicology, Vol. 17, No.1. Page: 24-38

11. Miriam Cnop, Nils Welsh, Jean-Christophe Jonas, Anne Jo, Sigurd Lenzen, and Decio L. Eizirik. 2005 Mechanisms of Pancreatic-Cell Death in Type 1 and Type 2 Diabetes. Many Differences, Few Similarities. Diabetes, Vol. 54, Supplement 2, December 2005. Page: S97-S-107

12. Ortis, Fernanda., Alessandra K. Cardozo, Daisy Crispim, Joachim Sto“ rling, Thomas Mandrup-Poulsen,and De' cio L. 2006. Eizirik. Cytokine-Induced Proapoptotic Gene Expression in Insulin-Producing Cells Is Related to Rapid, .Sustained, and Nonoscillatory Nuclear Factor-kappa_B Activation. Molecular Endocrinology 2006(8):1867-1879

13. Lee, Cathy C., Simin Liu. 2008 Role of Inflammatory Cytokines in Type 2 Diabetes. Review of Endocrinology, February 2008. Page: 19 -21

14. Perkumpulan Endokrinologi Indonesia (PERKENI). 2007.Konsensus Pengelolaan Diabetes Melitus di Indonesia. Jakarta 2007a

15. Hadisaputro, S., Riwanto,Ig., Subagio, H.W, Judiono, Laksono,B., Watuguly, T. 2008.Pendekatan Pengobatan Tradisional Untuk Tatalaksana Penyakit Infeksi HIV/AIDS dan Penyakit Degeneratif (Diabetes Mellitus dan Kanker Paru). Laporan Akhir Hibah Pasca Sarjana Universitas Diponegoro, 2008

16. Brown, Amy C., Ana Valiere. 2004. Probiotics and Medical Nutrition Therapy, Nutr Clin Care. 2004 ; 7(2): 56-68

17. Sybesma, W.F., Hugenholtz. 2004. Food fermentation by lactic acid bacteria for prevention of cardiovascular. Functional foods, cardiovascular disease and diabetes. England: Woodhead Publishing Limited, 2004: page: 448-469

18. Khazrai, Y.M., S Manfrini and P. Pozzilli. 2004. Diet and diabetes: prevention and control. Functional foods, cardiovascular disease and diabetes. England: Woodhead

19. Virtanen, S.M. 2004.Nutritional risk factors in the development of type 1 and type 2 diabetes. Functional foods, cardiovascular disease and diabetes. England: Woodhead Publishing Limited, 2004: page: 142-148

20. Almatsier, Sunita. 2003. Prinsip Dasar Ilmu Gizi, Gramedia Pustaka Utama. Jakarta, 2003

21. Meier, JJ. 2008. Beta cell mass in diabetes: a realistic therapeutic target. Diabetologia (2008) 51: 703-713

22. Susetia-Totoprajogo, Ongko. 2010. Probiotic and Gut Immune System. Makalah Malang Nutrition Up Date, Mei 2010

23. Hulley, Stephen B., Cumming, Steven R., Grady, Deborah. 2007 Designing a Randomized Blinded Trial, Chapter 10. Designing Clinical Research, 3rd Edition. Philadelphia, USA: Lippincott Williams \& Wilkins. Page: 147-161

24. Judiono, RRJ. Djokomoeljanto, Suharyo Hadisaputro. Biomolecular Aspects of Clear Kefir antidiabetic Potentials. IJFNPH http://www.worldsustainable.org/index.php/component/docman/cat_view/127- 
international-journal-of-food-nutrition-a-public-health/175-ijfnph-v5-nos123-

2012? limit $=5 \&$ order $=$ date $\&$ dir $=$ DESC \&start $=10$

25. Takeda, Kiyoshi, Shizuo Akira. 2004. TLR signaling pathways. Seminars in Immunology 16 (2004). Page: 3-9

26. Maeda, Hiroaki., Xia Zhu, Kazunobu Omura, Shiho Suzuki, Shinichi Kitamura. 2004.Effects of an exopolysaccharide (kefiran) on lipids, blood pressure, blood glucose, and constipation. BioFactors Vol. 22, Issue 1-4 (2004). Page: 197-200 